\title{
Regeneration of some monocotyledonous plants from subterranean organs in vitro
}

\author{
KRYSTYNA D. KROMER \\ Botanical Garden of Wroclaw University, ul. Sienkiewicza 23, 50-335 Wrodaw, Poland
}

(Recived: August 19, 1983)

\begin{abstract}
The aim in view was investigation of the regenerative potential of rhizomes, bulbs and corms of ten monocotyledonous plant species from four families: Amaryllidaceae (Haemanthus katharinae, Crinum abyssinicum, Leucojum vernum), Araceae (Spathiphyllum wallisii), Iridaceae (Crocus vernus, Iris germanica), Liliaceae (Hosta lancifolia, Muscari racemosum, Scilla laxiflora, Veltheimia viridifolia) under conditions of in vitro culture. All the investigated species were capable of buld or, alternatively, bud and root regeneration. Different morphogenetic potential was noted between the particular families. A high regenerative potential under the conditions of culture applied was characteristic for plants of the Liliaceae and Araceae families, it was lower in plants belonging to Amary'lidaceae and lowest in those of the Iridaceace family. Plants from the Liliaceae family exhibited also the highest ability of callus formation, whereas Amaryllidaceae and Iridaceae plants possessed this ability in only a low degree. The influence of growth regulators of the auxin group (NAA, IAA, 2,4-D) and of cytokinins (K) on the initiation and course of organogenesis was tested. The results of the experiments indicate that auxins in interaction with kinetin gave the highest percentage of regenerating explants and also a large number of buds on the latter. Stimulation of callus tissue was highest under the influence of 2,4-D, and weaker when NAA IAA were used.
\end{abstract}

\section{INTRODUCTION}

The technique of in vitro tissue culture dynamically developing in recent years found wide application in mass vegetative multiplication of plants and, above all, in investigations of processes of morphogenesis.

Many valuable and horticulturally important plants with bulbs and rhizomes belong to several monocotyledonous families: Liliaceae, Amaryllidaceae, Iridaceae, Araceae. In horticulture practice they are multiplied above all vegetatively, and lately great possibilities of their rapid multiplication have arisen, owing to the application of the method of tissue culture in vitro. 
Research on the vegetative growth of monocotyledonous plants in vitro progresses in many directions and comprises culture of meristems $(\mathrm{H} \mathrm{a} \mathrm{m} \mathrm{m} \mathrm{e}$, 1976; K u k l c z a n a and S a r os i e k, 1971; F o n n e b e c h, 1975; P i e r k and $\mathrm{S} \mathrm{t}$ e e $\mathrm{g} \mathrm{m}$ a n s, 1976b), induction of lateral shoots (F r i d b o r g, 1971; H a v r á e k and N ow a k, 1973; P i r i k, 1976) and embryos in callus culture ( $\mathrm{R}$ e $\mathrm{u} t \mathrm{~h}$ e $\mathrm{r}, 1977$ ), as well as induction of regeneration directly on isolated tissues ( $\mathrm{K} \mathrm{u} \mathrm{k} \mathrm{u} \mathrm{c} \mathrm{zan} \mathrm{k} \mathrm{a}$ and Prrę d o t a, 1974; Pi e r i k and I p pe 1, 1977; H u s e y, 1975).

Regeneration of bulbs from is olated scale leaves is well known and utilized in their vegetative multiplication. The technique of tissue culture increases the possibility of obtaining plants from various organs such as fragments of inflorescences ( $\mathrm{H}$ u s s e y, 1977), and shoots ( $\mathrm{H} \mathrm{u}$ s s e y, 1976a). Fragments of scales are, however, most productive in vitro $(\mathrm{H} \mathrm{a} \mathrm{c} \mathrm{k} \mathrm{e} \mathrm{t} \mathrm{t,} \mathrm{1969;} \mathrm{P}$ i e r i k and $\mathrm{P}$ o s t, 1975; $\mathrm{R}$ o b b, 1957).

It has been demonstrated that initiation of organized growth leads to changes in metabolism ( $\mathrm{T} \mathrm{h}$ or p e, 1978) and causes phytohormones to play an important role in this process ( $\mathrm{V} \mathrm{a} \mathrm{r} \mathrm{d} \mathrm{j} \mathrm{a} \mathrm{n}$ and $\mathrm{N}$ i t s c h, 1961). Differentiation of organs in tissue culture occurs owing to interaction of auxins and cytokinins, and the quantitative ratio of these two groups of growth regulators is essential here (S k o o g and M i 1 le r, 1957). A knowledge of hormonal regulation of regeneration processes will make possible introduction of the technique of tissue cultures in vitro of the investigated species into horticultural practice.

The aim of the present study was:

1. investigation of the regenerative potential of valuable ornamental plants from the families: Liliaceae, Amaryllidaceae, Iridaceae and Araceae;

2. gaining of a knowledge of the influence of growth regulators of the groups of auxins and cytokinins on regeneration processes in the investigated plants in vitro.

\section{METHODS}

The objects investigated were subterranean organs of ten monocotyledonous plant species from four families, taken from the colections of the Botanical Garden of the Wrockaw University. Experiments on subterranean organs regeneration in in vitro culture were performed in the spring and summer in the years $1975-1980$.

The plant material was disinfected with $0.5 \%$ sublimate for $2-5 \mathrm{~min}$ in dependence on the species and washed thrice in sterile distilled water.

The explants for the experiments were isolated differently according to the type of organ and species. 
BULBS

The basal halves of bulbs were divided by a vertical section into four or eight parts, depending on their size, and the central scales were discarded. The isolated explants consisted of fragments of 2-3 scales. As regards bulbs of the species Muscari racemosum (L.) Mill., Scilla laxiflora Baker, Leucojum vernum L., only a small fragment of the basal plate was left, and the species Veltheimia viridifolia(L.) Jacq., Haemanthus katharinae Baker and Crinum abyssinicum Hochst. explants consisted in one half of the basal plate and in the other half of the scales growing from it.

\section{RHIZOMES}

Annual increments of Iris germanica rhizomes, varieties 'Inspiration', 'Firecracker', 'Hi Time' and rhizomes of Spathiphyllum wallisii Regel. were cut horizontally into $1-\mathrm{cm}$ segments from which the outer layers of tissue were discarded and explants of $1.1 \times 0.6 \mathrm{~cm}$ were isolated. The current year increment of Iris germanica, variety 'Firecracker' and the species Hosta lancifolia (Thbg.) Engl. were collected with fragments of growing leaves, and the outer tissue layers were discarded so that the explant consisted in one half of the growing fragments of leaves and in its second half of current year rhizome increments.

\section{CORMS}

Corms of Crocus vernus cv. 'Grosse Gelbe' were cut into segments $1 \mathrm{~cm}$ thick along the long axis. The bud was removed from the central slice and so were the basal plate and the outer tissue layers.

The explants were singly placed in test tubes containing $2.5 \mathrm{ml}$ of medium and immersed to one half of their height. The culture was transferred to a culture room with thermoregulation at $25^{\circ} \pm 2^{\circ} \mathrm{C}$ under continuous light of $2700 \mathrm{~lx}$ of mixed light from fluorescent tubes of type Cool White, Day Light and Flora.

Medium of $\mathrm{Murashige}$ and $\mathrm{Sk}$ o o g (1962) was used in the experiments, $\mathrm{pH} 6.0$, after autoclaving, solidified by $0.8 \%$ agar. To the MS medium growth substances of the auxin and cytokinin groups were added. Auxins were applied in the form of naphthyl-1-acetic acid (NAA), 2,4-dichlorophenoxyacetic acid (2,4-D) and indolil-3-acetic acid (IAA). One cytokinin was used in the form of 6-furfurylaminopurpurine (K). In some cases ascorbic and citric acids were added in $1 \mathrm{mg} / \mathrm{dm}^{3}$ concentration.

The experiments were run in two combinations, a preliminary one comprising 20 replications (test tubes) and in the experimental combination proper (40 replications). The number of infected explants varied within the range of $2-25 \%$ in dependence on the species. 


\section{RESULTS}

AMAR YLLID ACEAE (CRINUM ABYSSINICUM HOCHST., HAEMANTHUS KATHARINAE BAKER, LEUCOJUM VERNUM L.)

Regeneration of adventitious bulbs of the enumerated species of the family Amaryllidaceae took place directly on the surface of the explant without participation of callus. The species Crinum and Haemanthus formed adventitious bulbs on the isolated part of the basal plate between two fragments of scales at their base, whereas they seldom formed on a fragment of the scale or the basal plate (Figs. 1, 2). Explants of Leucojum vernum formed bulbs on the inner surface of the scale, especially close to the wounded site, least frequently on both scale surfaces (Fig. 3). After eight weeks of culture leaves started growing from the formed Crinum abyssinicum bulblets. Only some bulbs of Haemanthus katharinae were capable of developing leaves, others remained in a state of rest. Roots formed at the base of only those bulbs which first developed leaves. Explants of $H$. katharinae with dormant bulblets were transferred to fresh medium, but they developed as late as after one year. All the bulblets formed by L. vernum did not develop leaves at all and their further development was inhibited. In order to induce growth, they were subjected to cooling for a period of 10-50 days, but this did not produce the expected results. As late as after 24 months, when the bulbs became much larger, development of first leaves and roots was observed. Regenerating explants of C. abyssinicum were transferred to fresh medium, where adventitious bulbs grew quickly forming an abundant root system (Fig. 4), and

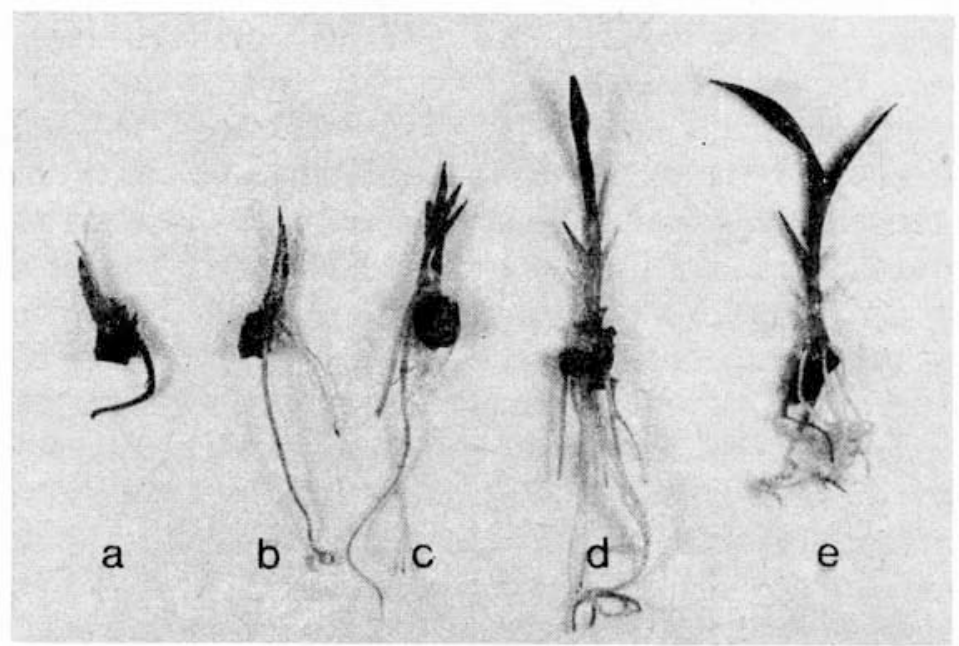

Fig. 1. Development of plantlets on segments of Crinum abyssinicum bulbs after: 8-week (a), 10-week (b), 12-week (c), 16-week (d) and 21-week (e) culture on MS medium with NAA (1 mg/dm $\left.{ }^{3}\right)$ and $\mathrm{K}\left(1 \mathrm{mg} / \mathrm{dm}^{3}\right)$ 


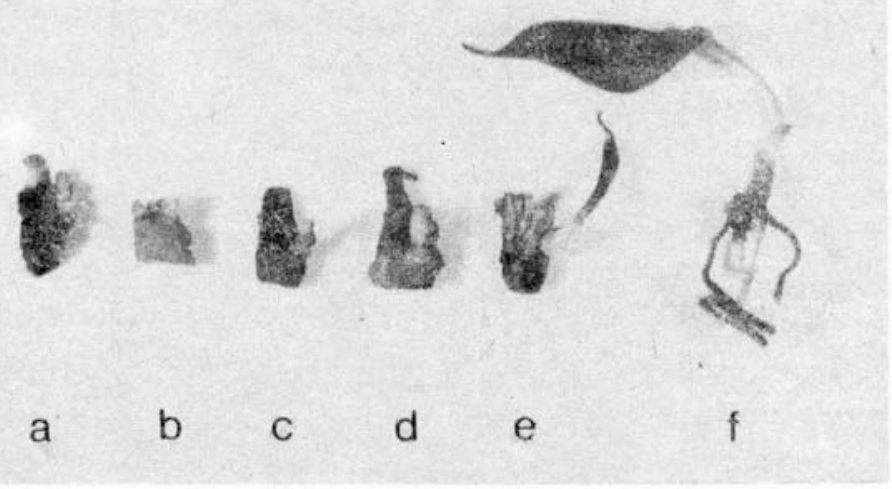

Fig. 2. Development of plantlets on segments of Haemanthus katharinae bulb after: 8-week (a, b), 12-week (c, d), 16-week (e), 21-week (f) culture on MS medium with 2,4-D (1 mg/dm $\left.{ }^{3}\right)$ and $\mathrm{K}\left(1 \mathrm{mg} / \mathrm{dm}^{3}\right)$

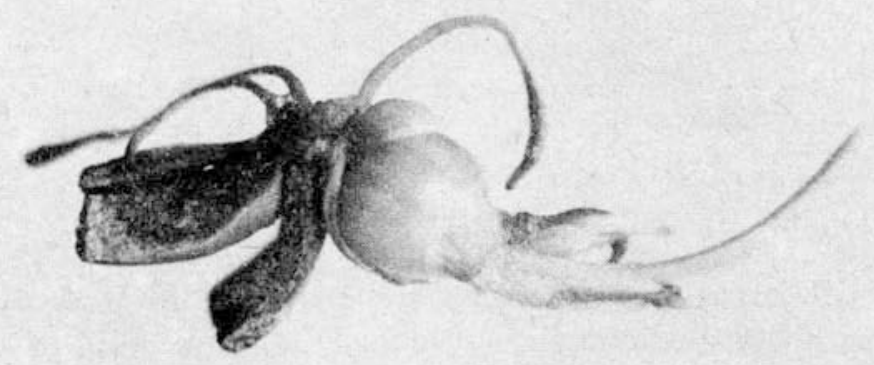

Fig. 3. Bulblets of Leucojum vernum grown for 24 months on MS medium with IAA $\left(2 \mathrm{mg} / \mathrm{dm}^{3}\right)$ and $\mathrm{K}\left(1 \mathrm{mg} / \mathrm{dm}^{3}\right)$

after one year, when transplanted into soil they readily adapted themselves to glasshouse conditions.

Formation of callus with a loose structure at the site of cut of the basal plate was noted on explants of Crinum and Haemanthus. The intensity of callus growth depended on the auxins contained in the medium, especially NAA and 2,4-D stimulated its development (Table 1). Explants of $H$. katharinae produced callus more profusely than those of $C$. abyssinicum. On the MS medium and its combination with growth regulators explants of $L$. vernum did not form callus tissue. 


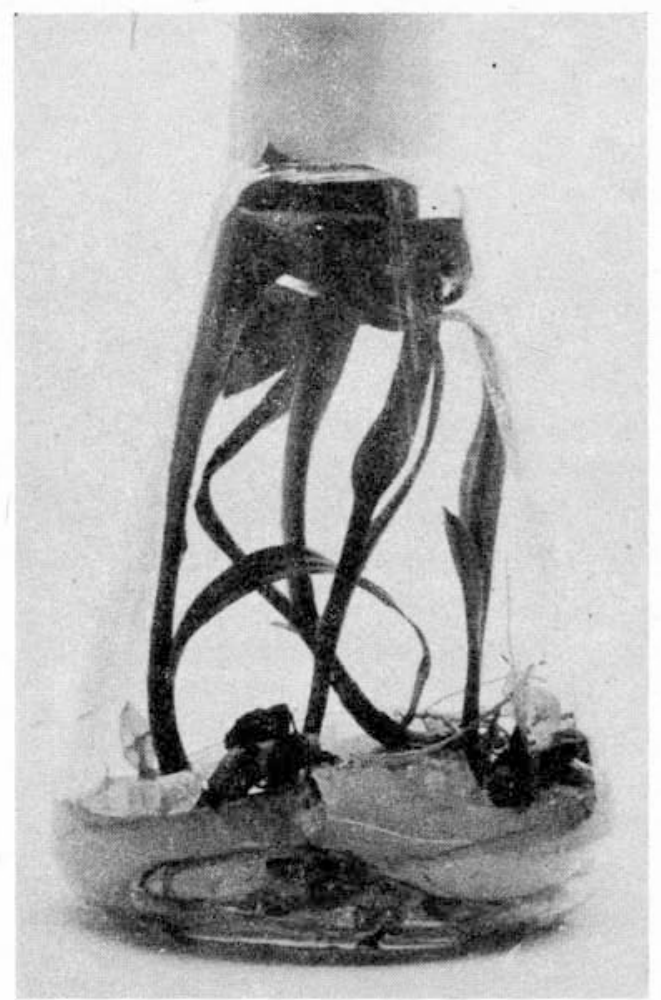

Fig. 4. Crinum abyssinicum plantlets after 12-month culture on MS medium IAA $\left(2 \mathrm{mg} / \mathrm{dm}^{3}\right)$ and $\mathrm{K}\left(1 \mathrm{mg} / \mathrm{dm}^{3}\right)$

A poor $(4-30 \%)$ regeneration ability of explants of the studied species was noted on control MS medium. Kinetin added to the medium usually did not increase the number of regenerating explants. The effect of kinetin was manifested in the formation of a larger number of bulblets on the explant. A lack of growth regulators or addition of solely kinetin to the medium caused the death of about one half of $H$. katharinae explants.

Most successful regeneration of $C$. abyssinicum (Table 1) reaching 38\% was obtained on medium containing auxin, NAA, or IAA with kinetin. Application of 2,4-D caused complete inhibition of organogenesis of this species. Addition of kinetin to medium containing 2,4-D did not abolish the inhibitory action of this auxin. Contrary as in the case of $C$. abyssinicum, medium with 2,4-D and kinetin initiated regeneration of the highest number of $H$. katharinae explants $(66 \%)$, (Table 1). Earlier initiation of adventitious H. katharinae bulbs and a better development of leaves and roots were observed on medium with higher NAA concentrations $\left(2 \mathrm{mg} / \mathrm{dm}^{3}\right)$ and 2,4-D added together with kinetin.

The effectiveness of all the auxins applied and their combinations with kinetin for Leucojum vernum was considerable $(70-90 \%)$. 
Ta b l e 1

Influence of growth regulat ors on formation of bulblets, roots and callus from subterranean organs of Amaryllidaceae plants after 21-week culture

\begin{tabular}{|c|c|c|c|c|c|c|c|}
\hline \multirow{2}{*}{$\begin{array}{l}\text { Growth } \\
\text { regulators } \\
\mathrm{mg} / \mathrm{dm}^{3}\end{array}$} & \multirow{2}{*}{$\begin{array}{c}\text { Bulblet } \\
\text { formation } \\
\%\end{array}$} & \multirow{2}{*}{$\begin{array}{l}\text { Avg. no. } \\
\text { of } \\
\text { bulblets } \\
\text { per } \\
\text { explant }\end{array}$} & \multirow{2}{*}{$\begin{array}{c}\text { Root } \\
\text { formation } \\
\%\end{array}$} & \multirow{2}{*}{$\begin{array}{l}\text { Avg. no. } \\
\text { of } \\
\text { roots } \\
\text { per } \\
\text { explant }\end{array}$} & \multirow{2}{*}{$\begin{array}{c}\text { Rooted } \\
\text { plantlets } \\
\%\end{array}$} & \multicolumn{2}{|c|}{ Callus } \\
\hline & & & & & & $\begin{array}{c}\text { formation } \\
\%\end{array}$ & $\begin{array}{l}\text { growth } \\
\text { intensity }\end{array}$ \\
\hline \multicolumn{8}{|c|}{ Crinum abyssinicum Hochst. } \\
\hline Control & 26.7 & 1.5 & 14.2 & 3.5 & 14.2 & 6.6 & + \\
\hline $1 \mathrm{~K}$ & 20.0 & 1.7 & 15.0 & 4.5 & 15.0 & 30.0 & ++ \\
\hline $1 \mathrm{NAA}$ & 32.7 & 1.3 & 27.6 & 4.7 & 17.6 & 23.5 & ++ \\
\hline $1 \mathrm{NAA}+1 \mathrm{~K}$ & 38.4 & 1.5 & 19.8 & 4.3 & 19.8 & 21.4 & $+t$ \\
\hline 2 IAA & 28.2 & 1.0 & 18.6 & 4.5 & 18.6 & 27.8 & ++ \\
\hline $2 \mathrm{IAA}+1 \mathrm{~K}$ & 36.3 & 1.2 & 18.7 & 3.7 & 18.7 & 26.3 & ++ \\
\hline $12,4-\mathrm{D}$ & 0 & 0 & 0 & 0 & 0 & 37.5 & ++ \\
\hline $12,4-D+1 K$ & 0 & 0 . & 0 & 0 & 0 & 25.1 & ++ \\
\hline \multicolumn{8}{|c|}{ Haemanthus katharinae Baker } \\
\hline Control & 4.4 & 1.0 & 0 & 0 & 0 & 0 & 0 \\
\hline $1 \mathrm{~K}$ & 11.0 & 2.0 & 0 & 0 & 0 & 11.0 & + \\
\hline 1 NAA & 8.8 & 1.0 & 8.8 & 1.0 & 0 & 56.3 & ++ \\
\hline $1 \mathrm{NAA}+1 \mathrm{~K}$ & 22.0 & 1.0 & 0 & 0 & 0 & 71.2 & ++ \\
\hline 2 NAA & 22.0 & 1.0 & 0 & 0 & 0 & 58.2 & +++ \\
\hline $2 \mathrm{NAA}+1 \mathrm{~K}$ & 33.3 & 1.0 & 12.0 & 1.0 & 12.0 & 100 & +++ \\
\hline 2 IAA & 33.3 & 1.0 & 0 & 0 & 0 & 66.6 & ++ \\
\hline $2 \mathrm{IAA}+1 \mathrm{~K}$ & 36.8 & 1.0 & 0 & 0 & 0 & 54.1 & + \\
\hline $12,4-D$ & 39.5 & 1.0 & 0 & 0 & 0 & 81.8 & $++t$ \\
\hline $12,4-D+1 K$ & 66.7 & 1.6 & 18.7 & 1.0 & 18.7 & 88.4 & ++ \\
\hline \multicolumn{8}{|c|}{ Leucojum vernum $\mathrm{L}$. } \\
\hline Control & 34.6 & 1.0 & 0 & 0 & 0 & 0 & 0 \\
\hline $1 \mathrm{~K}$ & 31.2 & 2.9 & 0 & 0 & 0 & 0 & 0 \\
\hline 1 NAA & 90.0 & 1.2 & 0 & 0 & 0 & 0 & 0 \\
\hline $1 \mathrm{NAA}+1 \mathrm{~K}$ & 85.7 & 1.5 & 0 & 0 & 0 & 0 & 0 \\
\hline 2 IAA & 88.8 & 1.0 & 0 & 0 & 0 & 0 & 0 \\
\hline $2 \mathrm{IAA}+1 \mathrm{~K}$ & 80.0 & 1.5 & 0 & 0 & 0 & 0 & 0 \\
\hline $12,4-D$ & 80.0 & 2.0 & 0 & 0 & 0 & 0 & 0 \\
\hline $12,4-D+1 K$ & 70.0 & 2.6 & 0 & 0 & 0 & 0 & 0 \\
\hline
\end{tabular}

+- very poor growth, ++- poor growth, +++- good growth, ++++- very good growth 
Fragments of Spathiphyllum wallisii rhizomes in experiments in vitro showed a different regeneration ability dependent on growth regulators, however, the course of regeneration was similar. After 4 weeks of culture there appeared on the explants green pointed meristematic centres (Fig. 5). They increased in size and differentiated to shoot buds, then developed rosettes at the base of which roots appeared (Fig. 6). The part of the explant not immersed in the medium was covered after a lapse of 21 weeks with regenerating plants. On explants which did not form buds, no formation of roots or callus was observed. Growth regulators applied in the medium greatly enhanced the regenerative ability (Table 2). Kinetin added to the medium in the presence of $2 \mathrm{mg} / \mathrm{dm}^{3}$ of NAA induced a somewhat different course of regeneration. After 12 weeks of culture there appeared on the surface of the growing explants large meristematic centres in the form of protuberances from which numerous buds developed. In the remaining combinations of media only one plant arose from one meristematic center.

Best results were obtained when NAA in $1 \mathrm{mg} / \mathrm{dm}^{3}$ concentration was added to the medium. Second as regards effect was auxin 2,4-D which stimulated formation of the greatest number of buds on the explant, whereas the largest number $(88 \%)$ of rooted plants was obtained on medium with $1 \mathrm{mg} / \mathrm{dm}^{3}$ NAA together with kinetin.

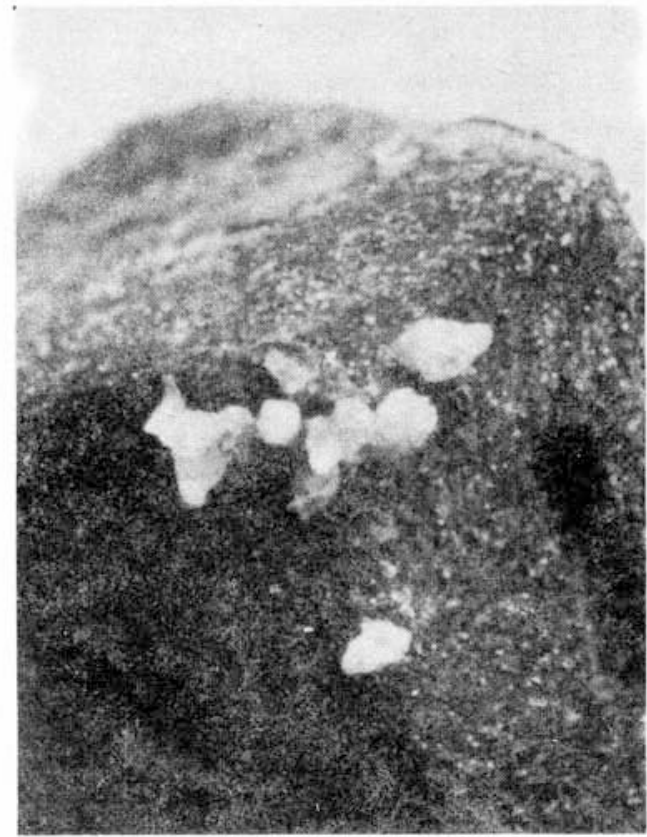

Fig. 5. Initiation of buds on a segment of Spathiphyllum wallisii rhizome after 8-week culture on MS medium with NAA $\left(1 \mathrm{mg} / \mathrm{dm}^{3}\right)$ 


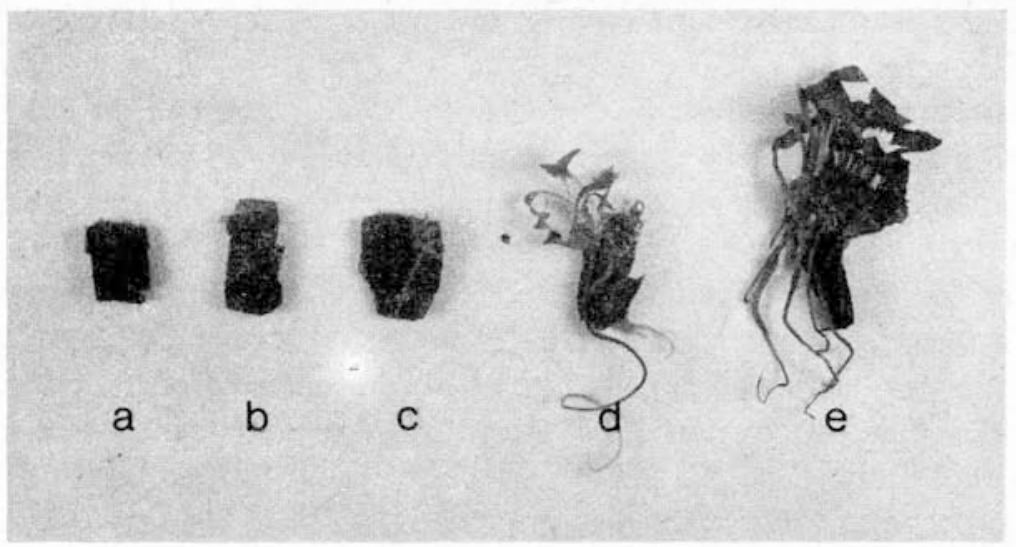

Fig. 6. Development of plantlets on segments of Spathiphyllum wallisii rhizome after: 8-week (a, b). 12-week (c), 16-week (d), 21-week (e) culture on MS medium with NAA $\left(1 \mathrm{mg} / \mathrm{dm}^{3}\right)$ and $\mathrm{K}\left(1 \mathrm{mg} / \mathrm{dm}^{3}\right)$

Ta b le 2

Influence of growth regulators on formation of buds, roots and callus from rhizome fragments of Spathiphyllum wallisii Regel. (Araceae) after 21-week culture

\begin{tabular}{lccccc}
\hline $\begin{array}{c}\text { Growth } \\
\text { regulators } \\
\text { mg/dm }\end{array}$ & $\begin{array}{c}\text { Bud } \\
\text { formation } \\
\%\end{array}$ & $\begin{array}{c}\text { Avg. no. } \\
\text { of buds } \\
\text { per explant }\end{array}$ & $\begin{array}{c}\text { Root } \\
\text { formation } \\
\%\end{array}$ & $\begin{array}{c}\text { Avg. no. } \\
\text { of roots } \\
\text { per explant }\end{array}$ & $\begin{array}{c}\text { Rooted } \\
\text { plantlets } \\
\%\end{array}$ \\
\hline Control & 11.1 & 5.0 & 5.5 & 2.0 & 5.5 \\
$1 \mathrm{~K}$ & 37.5 & 7.3 & 18.7 & 2.0 & 18.7 \\
$1 \mathrm{NAA}$ & 46.1 & 8.3 & 23.1 & 2.5 & 23.1 \\
1 NAA $+1 \mathrm{~K}$ & 88.8 & 10.3 & 77.7 & 5.0 & 77.7 \\
2 NAA $+1 \mathrm{~K}$ & 30.0 & 17.5 & 30.0 & 7.0 & 30.0 \\
2 IAA & 23.5 & 9.6 & 17.6 & 4.5 & 17.6 \\
2 IAA $+1 \mathrm{~K}$ & 17.6 & 7.0 & 11.8 & 2.0 & 11.8 \\
1 2,4-D & 35.3 & 20.0 & 23.5 & 2.0 & 23.5 \\
1 2,4-D $+1 \mathrm{~K}$ & 50.0 & 16.3 & 20.0 & 3.0 & 20.0 \\
\hline
\end{tabular}

IRIDACEAE (CROCUS VERNUS CV. 'GROSSE GELBE', IRIS GERMANICA)

Regeneration of both species of the family Iridaceae was very poor, buds formed only on some combinations with growth regulators in the medium.

Fragments of corm tissues of Crocus vernus formed after 12 weeks small white protuberances which further greatly elongated forming buds. The latter after 21 weeks of culture began to develop leaves. The regenerating explants were transferred to fresh media where, after further 12 weeks, rooting of the corms took place. Tests of the regenerative ability of fragments of Iris germanica rhizomes 
were performed in four experiments. In the first three performed successively in May ('Inspiration') June ('Firecracker') and July ('Hi Time') annual increments of the rhizome were collected. Only tissues of the rhizomes of the 'Hi Time' variety collected in July formed a green compact callus. For induction processes of organogenesis in tissues of Iris germanica rhizomes the parameters of the experiments were changed in June of the next year additional investigations were performed. Growth increments of the current year of rhizomes with fragments of leaves were collected from plants of the 'Firecracker' variety. Different combinations of medium were also applied, enriched in ascorbic and citric acids. After eight weeks of culture formation of green protuberances were noted on which shoot buds formed (Fig. 7). These buds, after another four weeks developed leaves, and then at their base roots appeared.

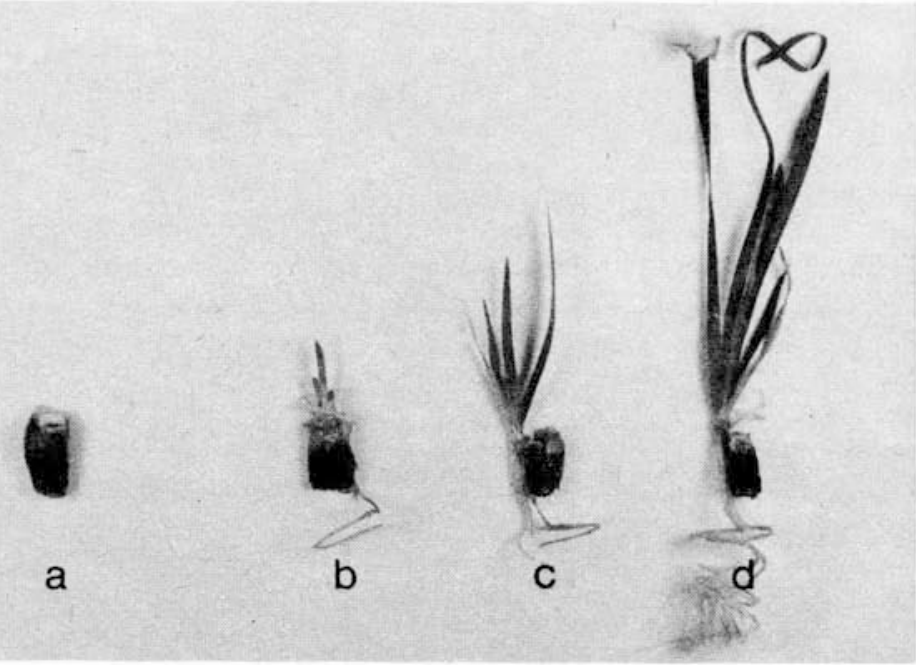

Fig. 7. Development of plantlets on segments of Iris germanica cv. 'Firecracker' rhizome after: 8-week (a), 12-week (b), 16-week (c), 21-week (d) culture on MS medium with IAA (2 mg/dm $\left.{ }^{3}\right)$

Formation of compact callus tissue occurred on the apical part of the explants of Iris germanica, and cream-white callus formed on the surface of the wound on C. vernus corms. Growth of callus was stimulated in C. vernus by NAA and 2,4-D and in $I$. germanica by NAA and IAA in a $2 \mathrm{mg} / \mathrm{dm}^{3}$ cencentration (Table 3 ).

Most numerous explants of $I$. germanica with regenerating buds $(21 \%)$ were found on medium containing $2 \mathrm{mg} / \mathrm{dm}^{3}$ IAA, and in the case of $C$. vernus best results $(16 \%)$ were obtained with medium containing NAA and kinetin (Table 3 ). Independently of the applied growth regulators, there appeared always only one bud on each explant of both species. 
T a b l e 3

Influence of growth regulators on formation of buds, roots and callus from subterranean organs of Iridaceae plants after 21-week culture

\begin{tabular}{|c|c|c|c|c|c|c|c|}
\hline \multirow{2}{*}{$\begin{array}{l}\text { Growth } \\
\text { regulators } \\
\mathrm{mg} / \mathrm{dm}^{3}\end{array}$} & \multirow{2}{*}{$\begin{array}{c}\text { Bud } \\
\text { formation } \\
\%\end{array}$} & \multirow{2}{*}{$\begin{array}{l}\text { Avg. no. } \\
\text { of buds } \\
\text { per } \\
\text { explant }\end{array}$} & \multirow{2}{*}{$\begin{array}{c}\text { Root } \\
\text { formation } \\
\%\end{array}$} & \multirow{2}{*}{$\begin{array}{l}\text { Avg. no. } \\
\text { of roots } \\
\text { per } \\
\text { explant }\end{array}$} & \multirow{2}{*}{$\begin{array}{c}\text { Rooted } \\
\text { plantlets } \\
\%\end{array}$} & \multicolumn{2}{|c|}{ Callus } \\
\hline & & & & & & $\begin{array}{c}\text { formation } \\
\%\end{array}$ & $\begin{array}{l}\text { growth } \\
\text { intensity }\end{array}$ \\
\hline \multicolumn{8}{|c|}{ Crocus vernus cv. 'Grosse Gelbe' } \\
\hline Control & 6.3 & 1 & 0 & 0 & 0 & 0 & 0 \\
\hline $1 \mathrm{~K}$ & 5.9 & 1 & 0 & 0 & 0 & 0 & 0 \\
\hline $1 \mathrm{NAA}$ & 7.2 & 1 & 0 & 0 & 0 & 81.7 & $++t$ \\
\hline $1 \mathrm{NAA}+1 \mathrm{~K}$ & 16.6 & 1 & 0 & 0 & 0 & 66.6 & +++ \\
\hline 2 IAA & 11.8 & 1 & 0 & 0 & 0 & 29.4 & ++ \\
\hline $2 \mathrm{IAA}+1 \mathrm{~K}$ & 0 & 0 & 0 & 0 & 0 & 35.8 & ++ \\
\hline $12,4-\mathrm{D}$ & 5.5 & 1 & 0 & 0 & 0 & 63.2 & ++ \\
\hline $12,4-D+1 K$ & 0 & 0 & 0 & 0 & 0 & 84.2 & ++ \\
\hline \multicolumn{8}{|c|}{ Iris germanica cv. 'Firecracker' } \\
\hline Control & 0 & 0 & 0 & 0 & $\mathbf{0}$ & 0 & 0 \\
\hline 1 NAA & 0 & 0 & 14.2 & 2 & 0 & 42.8 & ++ \\
\hline 2 NAA & 15.4 & 1 & 13.4 & 3 & 13.4 & 38.6 & +++ \\
\hline 3 NAA & 0 & 0 & 0 & 0 & 0 & 33.3 & ++ \\
\hline 4 NAA & 0 & 0 & 0 & 0 & 0 & 12.5 & ++ \\
\hline 2 IAA & 21.0 & 1 & 37.7 & 3 & 21.0 & 47.4 & +++ \\
\hline $2 \mathrm{IAA}+1 \mathrm{~K}$ & 0 & 0 & 0 & 0 & 0 & 52.6 & ++ \\
\hline $3 \mathrm{IAA}+1 \mathrm{~K}$ & 13.3 & 1 & 13.3 & 2 & 13.3 & 33.3 & ++ \\
\hline
\end{tabular}

+- very poor growth, ++- poor growth, +++- good growth, ++++- very good growth.

LILIACEAE (HOSTA LANCIFOLIA (THBG.) ENGL., MUSCARI RACEMOSUM (L) MILL., SCILLA LAX IFLORA BAKER, VELTHEIMIA VIRIDIFOLIA (L.) JACQ.)

Explants of the enumerated species of the Liliaceae family showed a characteristic high regenerative ability. The process of regeneration in vitro occurred very rapidly and, as early as after four weeks, adventitious bulblets could be seen or buds on the explants of Muscari racemosum, Scilla laxiflora and Hosta lancifolia, and, after eight weeks, on explants of Veltheimia viridifolia. Regeneration took place directly on fragments of bulbs and rhizomes without the participation of callus.

Bulblets of the species $M$. racemosum first formed close to the injured site, and later on the whole surface of the scale and they were not strongly attached to the tissue of the explant. In $S$. laxiflora buds formed usually on the inner side of the scale. Regeneration on explants of $V$. viridifolia took place on the isolated part of 
the stem plate between two fragments of scales at their base. Shoot buds of $H$. lancifolia differentiated from tissues at the base of leaves. After eight weeks of culture, there formed at the base of regenerating Hosta shoots an increasingly abundant root system. The well rooted plants developed after 12 weeks new adventitous shoots (Fig. 8). Bulblets of M. racemosum, S. laxiflora and V. viridifolia developed their first leaves after reaching a diametre of 3-4 mm (Fig. 9), and roots afterwards. Sporadically root formation directiy from scale fragments was observed.

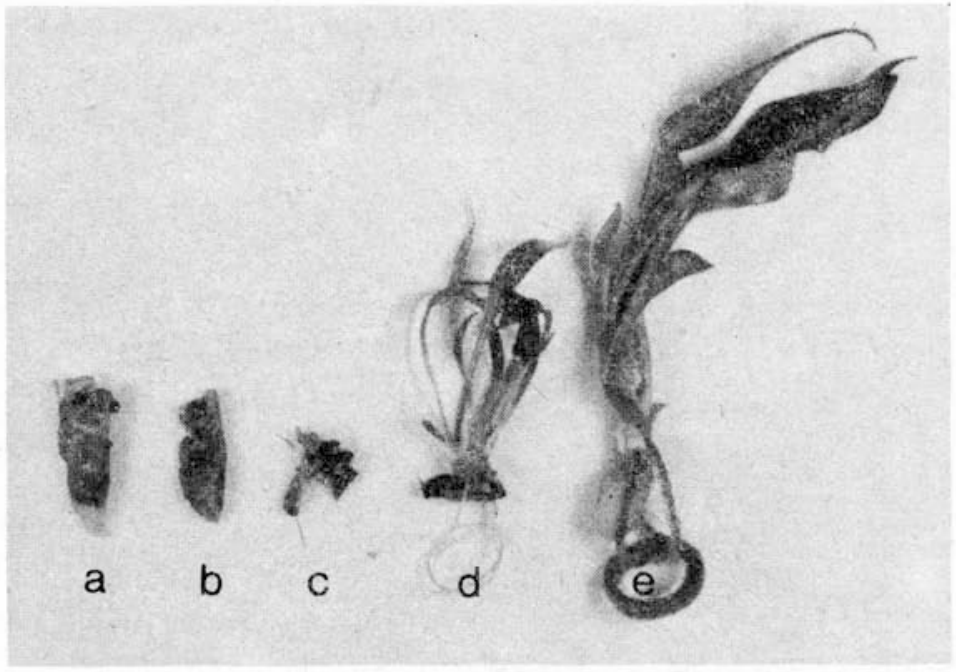

Fig. 8. Development of plantlets on segments of Hosta lancifolia rhizome after: 4-week (a, b), 8-week (c), 12-week (d), 16-week (e) culture on MS medium with 2,4-D $\left(1 \mathrm{mg} / \mathrm{dm}^{3}\right)$ and $\mathrm{K}\left(1 \mathrm{mg} / \mathrm{dm}^{3}\right)$

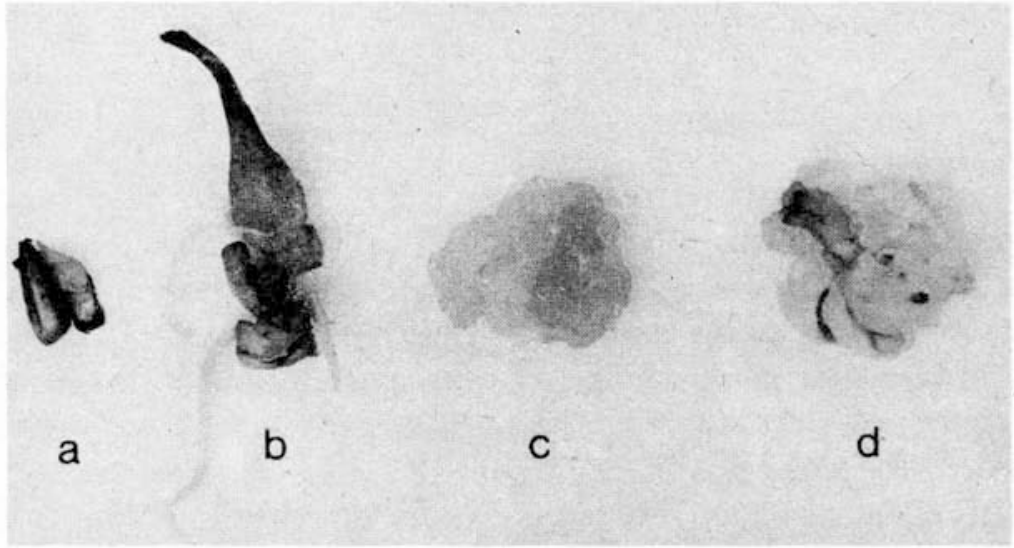

Fig. 9. Influence of growth regulators on regeneration of isolated bulb scale segments of Scilla laxiflora after 21-week culture on MS medium with: a) IAA $\left(2 \mathrm{mg} / \mathrm{dm}^{3}\right)$, b) NAA $\left(1 \mathrm{mg} / \mathrm{dm}^{3}\right)$ and $\mathrm{K}\left(1 \mathrm{mg} / \mathrm{dm}^{3}\right)$, c) 2,4-D $\left(1 \mathrm{mg} / \mathrm{dm}^{3}\right)$, d) $2,4-\mathrm{D}\left(1 \mathrm{mg} / \mathrm{dm}^{3}\right)$ and $\mathrm{K}\left(1 \mathrm{mg} / \mathrm{dm}^{3}\right)$ 
Callus growth in all the studied species of this family started from the wounded site, and on medium with 2,4-D gradually covered the whole surface of the explant (Fig. 9). The two remaining auxins (NAA and IAA) were less effective in inducing its growth. Green callus with compact structure formed on explants of $H$. lancifolia and the cream-coloured callus tissue of $M$. racemosum showed a loose structure. Explants of $S$. laxiflor a formed granular green callus, and in $V$. viridifolia it was cream-coloured. The ability of bud and root differentiation in callus tissue of $H$. lancifolia was observed sporadically on media with NAA and IAA and their combinations with kinetin after four months of culture. On the callus surface several protuberances appeared (Fig. 10). In passaged callus tissue of $M$. racemosum initiation of adventitious bulbs and ioots was also observed.

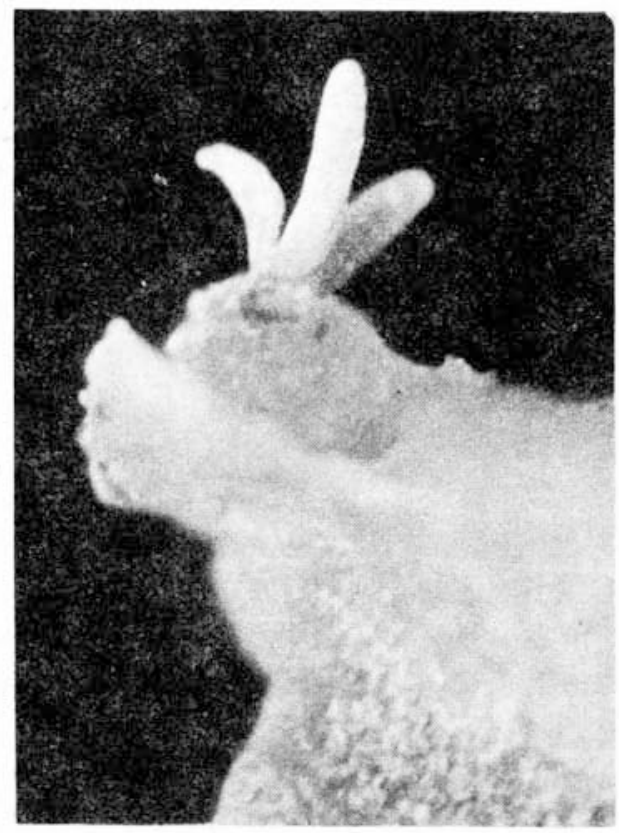

Fig. 10. Initiation of shoot buds from callus of Hosta lancifolia on MS medium with NAA $\left(1 \mathrm{mg} / \mathrm{dm}^{3}\right)$ and $\mathrm{K}\left(1 \mathrm{mg} / \mathrm{dm}^{3}\right)$ after 4-month culture

On control MS medium a regenerative ability of explants of all species was observed, the highest being in scales of $M$. racamosum bulbs $(81 \%)$. Addition of kinetin to the medium increased the number of buds and bulblets formed in all species with the exception of V.viridifolia explants (Table 4). Initiation of buds and roots of $H$. lancifolia was positively affected by 2,4-D and IAA, the highest percentage (81), however, of regenerating explants was obtained on medium containing $1 \mathrm{mg} / \mathrm{dm}^{3} 2,4-\mathrm{D}$ and $1 \mathrm{mg} / \mathrm{dm}^{3}$ kinetin. 
T a b 1 e 4

Influence of growth regulators on formation of buds, roots and callus from subterranean organs of Liliaceae plants after 21-week culture

\begin{tabular}{|c|c|c|c|c|c|c|c|}
\hline \multirow{2}{*}{$\begin{array}{l}\text { Growth } \\
\text { regulators } \\
\mathrm{mg} / \mathrm{dm}^{3}\end{array}$} & \multirow{2}{*}{$\begin{array}{c}\text { Bud } \\
\text { formation } \\
\%\end{array}$} & \multirow{2}{*}{$\begin{array}{l}\text { Avg. no. } \\
\text { of buds } \\
\text { per } \\
\text { explant }\end{array}$} & \multirow{2}{*}{$\begin{array}{c}\text { Root } \\
\text { formation } \\
\%\end{array}$} & \multirow{2}{*}{$\begin{array}{l}\text { Avg. no. } \\
\text { of roots } \\
\text { per } \\
\text { explant }\end{array}$} & \multirow{2}{*}{$\begin{array}{c}\text { Rooted } \\
\text { plantlets } \\
\%\end{array}$} & \multicolumn{2}{|c|}{ Callus } \\
\hline & & & & & & $\begin{array}{c}\text { formation } \\
\%\end{array}$ & $\begin{array}{l}\text { growth } \\
\text { intensity }\end{array}$ \\
\hline \multicolumn{8}{|c|}{ Hosta lancifolia (Thbg.) Engl. } \\
\hline Control & 21.0 & 1.0 & 21.0 & 5.0 & 20.0 & 15.8 & + \\
\hline $1 \mathrm{~K}$ & 47.1 & 1.4 & 52.6 & 6.4 & 47.4 & 57.8 & ++ \\
\hline $1 \mathrm{NAA}$ & 26.3 & 1.0 & 52.6 & 7.4 & 26.3 & 95.0 & +++ \\
\hline $1 \mathrm{NAA}+1 \mathrm{~K}$ & 18.8 & 1.0 & 31.3 & 5.5 & 18.8 & 75.1 & $+t+$ \\
\hline 2 IAA & 78.6 & 1.0 & 85.7 & 4.8 & 78.6 & 95.0 & +++ \\
\hline $2 \mathrm{IAA}+1 \mathrm{~K}$ & 36.8 & 2.2 & 46.6 & 7.0 & 36.8 & 52.6 & +++ \\
\hline $12,4-\mathrm{D}$ & 61.3 & 1.5 & 61.3 & 5.6 & 61.3 & 72.2 & +++ \\
\hline $12,4-D+1 K$ & 81.3 & 1.6 & 81.3 & 5.1 & 81.3 & 82.4 & ++++ \\
\hline \multicolumn{8}{|c|}{ Muscari racemosum (L.) Mill. } \\
\hline Control & 81.2 & 4 & 68.7 & 4 & 68.7 & 0 & 0 \\
\hline $1 \mathrm{~K}$ & 67.6 & 20 & 17.6 & 2 & 17.6 & 0 & 0 \\
\hline 1 NAA & 100 & 10 & 42.0 & 7 & 33.3 & 100 & $++t$ \\
\hline $1 \mathrm{NAA}+1 \mathrm{~K}$ & 100 & 15 & 55.5 & 6 & 55.5 & 100 & +++ \\
\hline 2 IAA & 100 & 10 & 100 & 11 & 100 & 70.0 & +++ \\
\hline $2 \mathrm{IAA}+1 \mathrm{~K}$ & 100 & 12 & 100 & 14 & 100 & 70.0 & +++ \\
\hline $12,4-\mathrm{D}$ & 100 & 7 & 50.0 & 5 & 50.0 & 100 & $+t+t$ \\
\hline $12,4-D+1 K$ & 50.0 & 7 & 10.0 & 2 & 10.0 & 100 & ++++ \\
\hline \multicolumn{8}{|c|}{ Scilla laxiflora Baker } \\
\hline Control & 26.6 & 1.2 & 11.5 & 1 & 11.5 & 0 & 0 \\
\hline $1 \mathrm{~K}$ & 38.5 & 3.6 & 8.8 & 1 & 7.2 & 0 & 0 \\
\hline 1 NAA & 60.5 & 1.9 & 22.2 & 3 & 22.2 & 33.3 & + \\
\hline $1 \mathrm{NAA}+1 \mathrm{~K}$ & 75.3 & 3.1 & 19.4 & 2 & 19.4 & 28.2 & + \\
\hline 2 IAA & 58.3 & 2.0 & 14.2 & 2 & 14.2 & 44.5 & ++ \\
\hline $2 \mathrm{IAA}+1 \mathrm{~K}$ & 66.2 & 2.8 & 11.1 & 3 & 11.1 & 35.6 & + \\
\hline $12,4-\mathrm{D}$ & 0 & 0 & 0 & 0 & 0 & 88.2 & $+t+t$ \\
\hline $12,4-D+1 K$ & 0 & 0 & 0 & 0 & 0 & 80.4 & $+++t$ \\
\hline \multicolumn{8}{|c|}{ Veltheimia viridifolia (L.) Jacq. } \\
\hline Control & 20.0 & 1 & 0 & 0 & 0 & 0 & 0 \\
\hline $1 \mathrm{~K}$ & 14.3 & 1 & 14.3 & 1 & 14.3 & 0 & 0 \\
\hline $1 \mathrm{NAA}$ & 52.3 & 1 & 52.3 & 2 & 49.8 & 0 & 0 \\
\hline $1 \mathrm{NAA}+1 \mathrm{~K}$ & 63.5 & 1 & 76.2 & 3 & 63.5 & 0 & 0 \\
\hline 2 IAA & 37.1 & 1 & 32.3 & 2 & 32.3 & 0 & 0 \\
\hline $2 \mathrm{IAA}+1 \mathrm{~K}$ & 45.7 & 1 & 45.7 & 2 & 45.7 & 0 & 0 \\
\hline $12,4-D$ & 0 & 0 & 0 & 0 & 0 & 85.3 & $++t+$ \\
\hline $12,4-D+1 K$ & 0 & 0 & 0 & 0 & 0 & 92.2 & ++++ \\
\hline
\end{tabular}




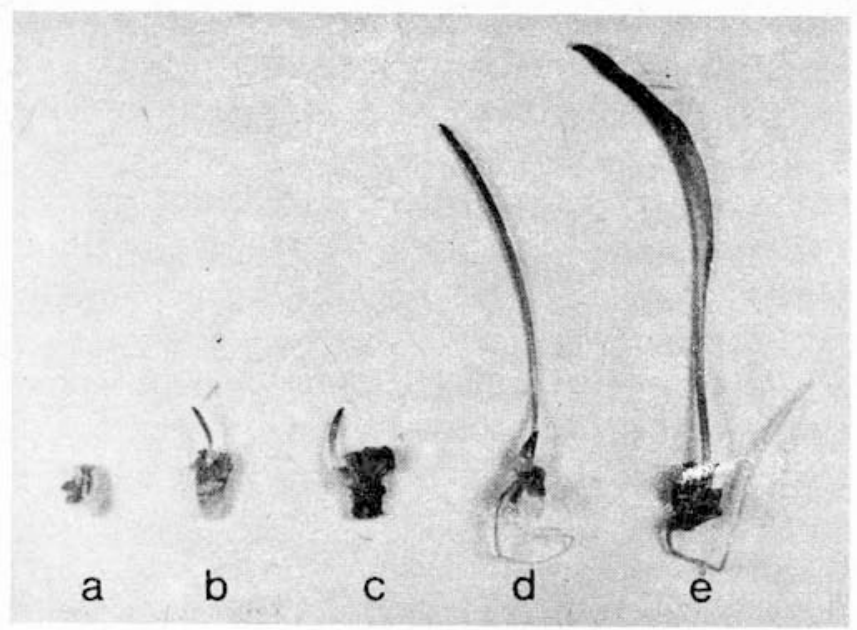

Fig. 11. Development of plantlets on segments of Veltheimia viridifolia bulb after: 8-week (a), 12-week (b, c), 16-week (d) and 21-week culture on MS medium with NAA $\left(1 \mathrm{mg} / \mathrm{dm}^{3}\right)$ and $\mathrm{K}\left(1 \mathrm{mg} / \mathrm{dm}^{3}\right)$

The auxins applied and their combinations with kinetin, with the exception of medium containing 2,4-D and kinetin induced bulb formation on all explants of $M$. racemosum, and increased their mean number on the explant (Table 4).

NAA and IAA added to the medium markedly increased the ability of bulb initiation in S. laxiflora and V. viridifolia (Fig. 11), but the best effects of Scilla $(75 \%)$ and V. viridifolia regeneration $(63 \%)$ were noted on media with NAA and kinetin. 2,4-D present in the media retarded the regenerative reaction of $M$. racemosum, completely inhibited bulb and root regeneration in S. laxiflora and $V$. viridifolia, whereas in the species $H$. lancifolia, when used with kinetin, stimulated regeneration of the greatest number of explants (Table 4).

On each explant of $\boldsymbol{V}$. viridifolia, independing the medium variant, only one bulb formed, whereas the remaining three species produced 2-20 buds on the explant.

The divided bulblets of Scilla and Muscari and fragments of Hosta rhizomes, when transferred to fresh medium regenerated once more a great number of plants on all explants.

\section{DISCUSSION}

REGENERATIVE POTENTIAL OF THE PLANTS

The investigated species of the families Liliaceae (Scilla laxiflora, Muscari racemosum, Hosta lancifolia, Veltheimia viridifolia) readily regenerated buds and roots under the given conditions of in vitro culture, even on media without 
growth regulators. A particularly high regenerative ability on control medium was observed for Muscari racemosum explants ( $81 \%$ ).

In dependence on the species and medium variant the number of explants regenerating buds reached $63-100 \%$. On a single explant 1 to 20 adventitious buds were noted. A similar readiness of bulb proliferation on fragments of Lilium speciosum scales was reported by $\mathrm{R}$ o b b (1957), H a c k e t t (1969), on Lilium longiflorum by A $11 \mathrm{e}$ n (1974), and on scales of Hyacinthus orientalis by Pie rik and Ruibing (1973), S a n e w s ki et al. (1974) and $\mathrm{P}$ i e r i k and $S$ t e e g ma $\mathrm{n} \mathrm{s}$ (1975). This leads to the conclusion that scales of bulbs from the Liliaceae family have a high regenerative potential.

$\mathrm{K}$ a $\mathrm{t} \mathrm{o}$ and $\mathrm{K}$ a w a h a r a (1972), when using media without growth regulators obtained bud initiation on isolated fragments of Heloniopsis orientalis, a high totipotency of Ornithogalum thyrsoides cells was also noted by $\mathrm{H}$ u s s e y (1976b). These results indicate that frequently wounding of tissues in plants of this family leads to initiation of cell division, this being a manifestation of a high regenerative potential of representatives of this family.

Rhizome fragments of the species Spathiphyllum wallisii, belonging to the family Araceae also showed a high regeneration ability conditioned by the application of a suitable medium variant. But formation on the explant surface occurred slowly, the first buds were observed after two months of culture. The slow course of regeneration of Caladium hortulanum on fragments of bulbs was observed by $\mathrm{Kuk} \mathrm{u} \mathrm{lczanka}$ and $\mathrm{Pr}$ e o t a (1974) and on leaf petioles of the same plant by K li m a s z e w s k a (1981).

Initiation of callus tissue on leaf fragments of Anthurium andraeanum was reported by $\mathrm{P}$ i e $\mathrm{r}$ i k (1976) after 3-4 months of culture. The slowly running dedifferentiation of cells, however, did not affect the effectiveness of morphogenesis processes observed in representatives of this family.

Explants of Spathiphyllum wallisii formed on the surface of the wound 7 to 20 adventitious plants. The investigations of $\mathrm{Ku} \mathrm{k} \mathrm{u} \mathrm{l} \mathrm{c} \mathrm{z} \mathrm{a} \mathrm{n} \mathrm{k} \mathrm{a} \mathrm{and}$ $\mathrm{P} r$ \& d o t a (1974) on Caladium indicate an extremely high regenerative potential of this species. A similarly high bud and root initiation in callus obtained from leaves of Anthurium andraeanum was observed by $\mathrm{P}$ i e r i k et al. (1974), and in the callus of Anthurium scherzerianum by $\mathrm{P}$ i e r i k and $\mathrm{S}$ t e e $\mathrm{g}$ m a n s (1976a).

Species belonging to the Amaryllidaceae family showed a lower regenerative ability than representatives of the family Liliaceae. Initiation of buds was even observed on medium without growth regulators added, however, a lower percentage of explants exhibited a morphogenetic reaction, both on control media and under the influence of the added growth substances. A single explant usually formed one or two buds. Fragments of Leucojum vernum bulbs were found to regenerate bulbs in a higher percentage than did the two remaining tested species: Haemanthus katharinae and Crinum abyssinicum. 
Regeneration of bulblets and their development on explants occurred slowly (between 8th and 12th week of culture). A similar slow regeneration was observed by $\mathrm{H}$ u s s e y (1975) in other plants of the Amaryllidaceae family.

Poorest regeneration under the given culture conditions was observed in the two species of the family Iridaceae: Iris germanica and Crocus vernus. Regeneration on basic medium happened sporadically on plants of this family.

In the investigations performed only a small number of explants of Crocus vernus corms and Iris germanica rhizomes regenerated buds and roots on several medium variants, and on a single explant only one bud always formed. $\mathrm{Z}$ i v et al. (1970) observed regeneration of buds and corms of Gladiolus hortulanus, initiated exclusively in callus from young flower stems. Callus obtained from bulbs of this plant was incapable of initiation of organs and died after several weeks of subculture.

\section{BUD INITIATION ON EXPLANTS}

Wide differences were observed in the experiments as regards the site of bud initiation within the families. In the Liliaceae family bulblets formed only on the scales of Scilla laxiflora and Muscari racemosum. In Hosta lancifolia and Veltheimia viridifolia buds formed at the base of leaves or scales. Explants of Leucojum vernum of the Amaryllidaceae family formed adventitions bulbs on the surface of scales and the remaining two species, Crinum abyssinicum and Haemanthus katharinae, at the base of the scales. Fragments of bulbs and rhizomes of plants of the family Iridaceae and Araceae formed adventitious shoots usually on the surface of wounded tissues.

It would seem that species of the family Liliaceae and Amaryllidaceae which formed buds directly on the scale surface had a higher dedifferentiation ability of somatic cells than those which formed buds only at the base of scales. On the basal plate in the axil of each fleshy leaf (scale) usually axillary, buds are present or groups of meristematic cells the initiation of which leads to bud formation ( $\mathrm{G}$ r o o t a a r t s et al., 1981; H u s s e y, 1982). Organization of bulbs on the scale surface occurs most frequently by division of epidermal and subepidermal cells ( $\mathrm{H}$ u s s e y, 1976b). Dedifferentiation of epidermal and subepidermal cells is a phenomenon frequently observed in the Liliaceae family (M o r e l, 1974).

\section{CALLUS TISSUE INITIATION ON EXPLANTS}

Among the ten investigated plant species strong callus tissue growth was observed on explants of three species (Muscari racemosum, Hosta lancifolia, Scilla laxiflora). The remaining five species formed less vigorous callus (Crinum absyssinicum, Iris germanica, Veltheimia viridifolia, Haemanthus katharinae, Crocus vernus), and two species (Spathiphyllum wallisii, Leucojum vernum) did not form any callus at all. 
The family Liliaceae explants showed the highest ability of callus tissue formation on the medium variants applied. Tissues of the subterranean organs of representatives of the families Amaryllidaceae and Iridaceae in the same combinations with growth regulators reacted by poorer callus formation. Similat results in callus formation on explants of representatives of the families Liliaceae, Amaryllidaceae and Iridaceae were obtained by $\mathbf{H}$ u s s e y (1975).

Growth regulators variously affected callus tissue initiation. Maximal callus growth was observed under the influence of 2,4-D. The influence of this growth regulator was most pronounced in the Liliaceae family, where callus formed on media with this auxin was most profuse. A strong stimulation of callus growth in monocotyledonous plants by this auxin was also reported by $\mathrm{Hu} \mathrm{n} \mathrm{a} \mathrm{u} 1 \mathrm{t}$ $(1978 ; 1979 \mathrm{a}, \mathrm{b}, \mathrm{c}, \mathrm{d})$.

The presence of kinetin in the medium induced in some species very weak callus tissue formation, and in others had no influence on this process. Similar results were obtained by $\mathrm{H} \mathrm{u} \mathrm{n}$ a $\mathrm{u} 1 \mathrm{t}$ (1979d). Kinetin application with auxin reduced as a rule excessive growth of callus tissue.

$\mathrm{H} \mathrm{u} \mathrm{n}$ a u $1 \mathrm{t}$ (1979d), S e a b r o o k et al. (1976) suggest that the tissues of monocotyledonous plants produce callus when active auxins are added to the medium or when the concentration of less active auxins is increased. The causes of this fact result from the different than in dicotyledons anatomical structure of monocotyled onous plants.

INFLUENCE OF GROWTH REGULATORS ON BUD AND ROOT FORMATION

The influence of growth regulators on the process of organogenesis in monocotyledons is so far not completely known, there are on this subject many controversial reports. H u s s e y (1976b) affirms that it is mainly auxins that control the processes of morphogenesis in the tissues of Ornithogalum bulbs. According to $\mathrm{P}$ i e r i k and W o e t s (1971) kinetin in the concentration applied $\left(0.01-10 \mathrm{mg} / \mathrm{dm}^{3}\right)$ had no effect on regeneration and the number of forming hyacinth bulbs. In the experiments of $\mathrm{G} \mathrm{i} \mathrm{z} \mathrm{b} \mathrm{u} \mathrm{r} \mathrm{g}$ and $\mathrm{Z} \mathrm{i} \mathrm{v} \mathrm{(1973),}$ on the other hand, kinetin was the only substance inducing adventitious cormlet formation in Gladiolus.

In the present experiments kinetin enhanced the number of forming buds on the explant, whereas it had no decisive effect on the number of explants regenerating buds. The weak regenerative reactions under the influence of kinetin alone may result from the high cytokinin activity found in extracts of Hosta lancifolia and Muscari racemosum tissues taken for the experiment (unpublished data). The effectiveness of the three auxins with different biological activity depended mainly on the species. Application of the appropriate auxin together with kinetin conditions achievement of highest regeneration. Most species were stimulated to formation of a large number od bulblets or of buds by the 
application of NAA with kinetin: Muscari racemosum $(100 \%)$, Scilla laxiflora $(75 \%)$, Veltheimia viridifolia $(63 \%)$, Crinum abysynnicum $(38 \%)$, Leucjoum vernum $(85 \%)$ and Spathiphyllum wallisii $(88 \%)$.

2,4-D in a dose of $1 \mathrm{mg} / \mathrm{dm}^{3}$ had different effects on the subterranean organs: it delayed regeneration of Muscari racemosum bulbs, and in interaction with kinetin partly inhibited their formation. $R$ a o et al. (1973) found that 2,4-D in combination with BA inhibits development of shoot buds on explants of Petunia shoots and leaves. The same auxin inhibited completely morphogenesis in the species Veltheimia, Scilla, Crinum and Crocus. A similar reaction to 2,4-D was noted by $\mathrm{K} \mathrm{a} \mathrm{u} \mathrm{l}$ and $\mathrm{S} \mathrm{a} \mathrm{b} \mathrm{h} \mathrm{a} \mathrm{r} \mathrm{wa} \mathrm{l}$ (1972) in Haworthia callus. A stimulating effect of 2,4-D was observed in Hosta lancifolia and Haemanthus katharinae. Tissues of subterranean organs of this species probably require for induction of a large number of buds higher auxin doses, therefore, the most active auxin gave the best results, especially in interaction with kinetin.

Tissue cultures in vitro of the investigated plants of the Liliaceae family, the regeneration of which reaches $80-100$ per cent should find application in horticular practice, since they possess an extremely high regenerative potential. The formed buds or bulblets continuously divided produce adventitious buds. This supplies as effect thousands of plants in the course of one year. Species belonging to the Amaryllidaceae family which form bulbs on 40-80 per cent of explants can also be rapidly multiplied in in vitro culture, however, a period of required cooling has to be taken into account, this prolonging the time of production of the plants. All the tested species rooted readily. As the leaves developed, roots formed spontaneously at the base of the bulblets and shoots. Neither is adaptation of plants from cultures under glasshouse conditions difficult, since bulbs are well protected by nature from excessive loss of water. An additional asset in the investigations performed is regeneration of buds directly from the explant tissues without callus participation, this ensuring the maintenance of a genetically stable material.

\section{CONCLUSIONS}

1. Fragments of subterranean organs of the examined plants in in vitro cultures were capable of bud, adventitious bulb and root regeneration. Their morphogenetic potential, however, differed:

(a) it was high in species of Liliaceae (Hosta lancifolia, Muscari racemosum, Scilla laxiflora,.Veltheimia viridifolia) and of Araceae (Spathiphyllum wallisii);

(b) it was lower in species of Amaryllidaceae (Crinum abyssinicum, Haemathus katharinae, Leucojum vernum);

(c) it was lowest in species of Iridaceae (Crocus vernus, Iris germanica cv. 'Firecracker'). 
2. The investigated plants from four families differed in their ability of callus formation:

(a) Liliaceae exhibited the highest ability;

(b) Amaryllidaceae and Iridaceae showed a relatively low one;

(c) Spathiphyllum wallisii of the Araceae family formed none.

3. Initiation and growth of callus tissue was most intensively stimulated by auxin 2,4-D, and weaker by auxins NAA and IAA.

4. Growth regulators in the medium favoured regeneration of plants from fragments of subterranean organs:

(a) kinetin only slightly affected the number of explants regenerating buds, but it distinctly enhanced their number on a single explant;

(b) auxins increased the number of explants regenerating buds and roots;

(c) auxins in interaction with kinetin induced the highest percentage of regenerating explants and a large number of buds on a single explant.

5. The high percentage of regenerating plants makes possible application of the tissue culture technique in vitro to the tested plants in horticular practice. For their rapid multiplication the following media are recommended:

(a) $1 \mathrm{mg} / \mathrm{dm}^{3}$ NAA with $1 \mathrm{mg} / \mathrm{dm}^{3}$ kinetin for the species:Muscari racemosum $(100 \%)$, Scilla laxiflora $(75 \%)$, Veltheimia viridifolia $(63 \%)$, Crinum abyssinicum $(38 \%)$, Leucojum vernum $(85 \%)$, Spathiphyllum wallissi $(88 \%)$;

(b) $1 \mathrm{mg} / \mathrm{dm}^{3}$ 2,4-D with $1 \mathrm{mg} / \mathrm{dm}^{3}$ kinetin for the species: Hosta lancifolia $(81 \%)$, Haemanthus katharinae $(66 \%)$.

6. Regeneration of the highest number of explants of species of Iridaceae was stimulated by media with the addition of

(a) $1 \mathrm{mg} / \mathrm{dm}^{3}$ NAA together with $1 \mathrm{mg} / \mathrm{dm}^{3}$ kinetin for Crocus vernus $(16 \%)$;

(b) $2 \mathrm{mg} / \mathrm{dm}^{3}$ IAA for the species Iris germanica cv. 'Firecracker' $(21 \%)$.

7. Rooting of the tested species occurred readily and did not require special media, root initiation took place spontaneously with development of the leaves.

The author is greatly indebted to Prof. Dr Krystyna Kukułczanka for her guidance in the course of the present study.

\section{REFERENCES}

A 11 e.n T. C., 1974. Production of virus free lilies. Acta Hort. 36: 235-239.

F o n n e s b e c h M., 1975. Cultivation of Asparagus plumosus shoot tips in vitro with special reference to vegetative propagation. Acta Hort. 54: 93-94.

F r i d b o r g G., 1971. Growth and organogenesis in tissue cultures of Allium cepa var. proliferum. Physiol. Plant. 25: 436-440.

$\mathrm{G}$ i n z b u r g C., Z i v M., 1973. Hormonal regulation of cormel formation in Gladiolus stolons grown in vitro. Ann. Bot. 37: 219-224.

G r o o t a a r t s H., S c h e 1 I. H. N., P i e r i k R. L. M., 1981. The origin of bulblets formed on excised twin scales of Nerine bowdenii W. Watts. Plant Cell Tissue Culture 1: 39-46. 
H a c k e t t W. P., 1969. Aseptic multiplication of lily bilblets from bulb scales. Proc. Intern. Plant Prop. Soc. Ann. Meeting 19: 105-108.

H a m m e r P. A., 1976. Tissue culture propagation of Hosta decorata Bailey. Hort. Science $11(2) 309$.

H a v r á n e k P., N o vá k F.J., 1973. The bud formation in the callus cultures of Allium sativum. L. Z. Pflanzenphysiol. 68: 303-318.

H u n a u 1 t G., 1978. Recherches sur le comportement des fragments d'organes et des tissus de Monocotylédones cultivés in vitro. I. Cosidérations historiques. Rev. Gén. Bot. 85: 305-351.

H u n a u 1 t G., 1979a. Recherches sur le comportement des fragments d'organes et des tissus Monocotyléd ones cultivés in vitro. II. Étude du cas quelqes Agavacées, Rev. Cytol. Biol. Végét. Bot. 2: 21-66.

H u n a u l t G., 1979b. Recherches sur le comportement des fragments d'organes et des tissus de Monocotylédones cultivés in vitro. III. Étude du cas de plusieurs Liliacées. Rev. Cytol. Biol. Végét. Bot. 2: 103-154.

H u n a u 1 t G., 1979c. Recherches sur le comportement des fragments d'organes et des tissus de Monocotylédones cultivés in vitro. IV. Étude de quelques espéces appartenant á des familles autres que les Agavacées et les Liliacées. Rev. Cytol. Biol. Végét. Bot. 2: 231-258.

H u n a u 1 t G., 1979d. Recherches sur le comportement des fragments d'organes et des tissus de Monocotylédones cultivés in vitro. V. Discussion. Rev. Cytol: Biol. Végét. Bot. 2: 259-287.

H u s s e y G., 1975. Totipotency in tissue explants and callus of some members of the Liliaceae, Iridaceae and Amaryllidaceae. J. Exp. Bot. 26: 253-262.

H u s s e y G., 1976a. Propagation of Dutch iris by tissue culture. Scient. Hort. 4: 163-165.

H u s s e y G., 1976b. Plantlet regeneration from callus and parent tissue in Ornithogalum thyrsoides. J. Exp. Bot. 27: 375-382.

H u s s e y G., 1977. In vitro propagation of some members of the Liliaceae, Iridaceae and Amaryllidaceae. Acta Hort. 78: 303-309.

H u s s e y G., 1982. In vitro propagation of Narcissus. Ann. Bot. 49: 707-719.

K a t o Y., K a w a h a r a S., 1972. Bud formation in leaves, leaf fragments and midrib pieces of Heloniopsis orientalis (Liliaceae). Planta 107: 111-120.

K a u 1 K., S a b h.a r w a 1 P. S., 1972. Morphogenetic studies on Haworthia: establishment of tissue culture and control of differentiation. Amer. J. Bot. 59: 377-385.

K l i m a s z e w s k a K., 1981. Plant regeneration from petiole segments of some species in tissue culture. Acta Agrobot. 34: 5-28.

K u k u $\nmid$ c z a n k a K., P r e d o t a B., 1974. Restitutive regeneration in Caladium $\times$ hortulanum Birdsey tissue culture. Proceedings of the Internat. Hort. Congress Vol 1B: 842 Warszawa, September 1974.

K u k u 1 c z a n k a K., S a r o s i e k J., 1971. Merystematyczne kultury storczyków, Wiad. Bot. XV. $1: 29-41$.

M o r e 1 G. M., 1974. The orchids. Clonal multiplication of orchids. Ed. C. Withner N. York, London, Sydney, Toronto.

M u r a s h i g e T., S k o o g F., 1962. A revised medium for rapid growth and bioassays with tobacco tissue cultures. Physiol. Plant. 15: 473:497.

P i e r i k R. L. M., 1976. Anthurium andraeanum plantlets produced from callus tissues cultivated in vitro. Physiol. Plant. 37: 80-82.

P i e r i k R. L. M., I p p e I B. J., 1977. Plantlet formation from excised bulb scale segments of Nerine. Acta Hort. 78: 197-202.

P i e r i k R. L. M., P o s t A. J. P., 1975. Rapid vegetative propagation of Hyacinthus orientalis L. in vitro. Scient. Hort. 3: 293-297.

P i e r i k R. L. M., R u i b i n g M. A., 1973. Regeneration of bulblets on bulb scale segments of hyacinth in vitro. Neth. J. Agr. Sci. 2: 129-138. 
P i e r i k R. L. M., S t e e g m a n s H. H. M., 1975. Effect of auxins, cytokinins, gibberellins, abscisic acid and ethephon on regeneration and growth of bulblets on excised bulb scale segments of hyacinth. Physiol. Plant. 34: 14-17.

P i e r i k R. L. M., S t e e g m a n s H. H. M., 1976a. Vegetative propagation of Anthurium scherzerianum Schott through callus cultures. Scient. Hort. 4: 291-292.

P i e $r$ i k R. L. M., S t e e g m a n s H. H. M., 1976b. Vegetative propagation of Freesia through the isolation of shoots in vitro. Neth. J. Agric. Sci. 24: 274-277.

Pie rik R. L. M., S t e g m a s s H. H. M., va n De r Me y s J. A. J. 1974. Plantlet formation in callus tissues of Anthurium andraeanum Lind., Scient. Hort. 2: 193-198.

P i e r i k R. L. M., W o e t s J., 1971. Regeneration of isolated bulb scale segments of hyacinth. Acta Hort. 23: 423-428.

R a o P. S., H a n d r o W., H a r a d a H., 1973. Hormonal control of differentiation of shoots, roots and embryos in leaf and stem cultures of Petunia inflanta and Petunia hybr. Physiol. Plant. 28: 458-463.

R e u t h e r G., 1977. Embryoide Differenzierungsmuster in Kallus der Gattungen Iris und Asparagus. Ber. Deutsch. Bot. Ges. Bd. 90: 417-437.

R o b b S. N., 1957. The culture of excised tissue from bulb șcales of Lilium speciosum Thunb. J. Exp. Bot. 8: 348-352.

S a n i e w s k i M., N o w a k. J., R u d n i c k i R. M., 1974. Studies on the physiology of hyacinth bulbs. IV. Hormonal regulation of induction of roots and bulblets in Hyacinthus orientalis L. grown in culture. Plant Sci. Letters 2: 373-376.

$\mathrm{S}$ e a b r o ok J. E. A., C u $\mathrm{m} \mathrm{m}$ i n g B. G., D i o $\mathrm{n} \mathrm{n} \mathrm{e} \mathrm{L.} \mathrm{A.,} \mathrm{1976.} \mathrm{The} \mathrm{in} \mathrm{vitro} \mathrm{induction} \mathrm{of}$ adventitious shoot and root apices on Narcissus (daffodil and narcissus) cultivar tissue. Can. J. Bot. 54: 814-819.

$\mathrm{S} \mathrm{k} \mathrm{o} \mathrm{o} \mathrm{g} \mathrm{F.,} \mathrm{M} \mathrm{i} 11 \mathrm{e} \mathrm{r} \mathrm{C.} \mathrm{O.,} \mathrm{1957.} \mathrm{Chemical} \mathrm{regulation} \mathrm{of} \mathrm{growth} \mathrm{and} \mathrm{organ} \mathrm{formation} \mathrm{in} \mathrm{plant}$ tissues cultivated in vitro. [In:] Biological Action of Growth Substances. Symp. Soc. Exp. Biol. 11: 118-131.

T h o r p e T. A., 1978. Physiological and biochemical aspect of organogenesis in vitro. Proceedings of the 4th International Congress of Plant Tissue and Cell Culture, Calgary, 1978. 5: 49-59.

$\mathrm{V}$ a $\mathrm{rd} \mathrm{j}$ a $\mathrm{n}$ M., $\mathrm{N}$ i $\mathrm{t} \mathrm{s} \mathrm{c}$ h J. P., 1961. Le régéneration chez Cichorium endiva $\mathrm{L}$.: étude auxines et des 'kinines'endogénes. Bull. Soc. Bot. Fr. 108: 363-374.

Z i v M., H a l e v y A. H., S h i l o R., 1970. Organs and plantlets regeneration of Gladiolus through tissue culture. Ann. Bot. 34: 671-676.

\title{
Regeneracja wybranych gatunków roślin jednoliściennych $\mathrm{z}$ organów podziemnych $\mathrm{w}$ kulturach in vitro
}

\author{
St reszczen i e
}

Celem pracy było zbadanie potencjału regeneracyjnego cebul, kłączy i bulw 10 gatunków roślin jednoliściennych z 4 rodzin: Amaryllidaceae (Haemanthus katharinae, Crinum abyssinicum, Leucojum vernum), Araceae (Spathiphyllum wallisii), Iridaceae (Crocus vernus, Iris germanica), Liliaceae (Hosta lancifolia, Muscari racemosum, Scilla laxiflora, Veltheimia viridifolia) w warunkach kultury in vitro. Wszystkie badane gatunki odznaczały się zdolnością regeneracji cebulek bądź alternatywnie pąków oraz korzeni. Stwierdzono zróżnicowany potencjal morfogenetyczny między poszczególnymi rodzinami. Wysoki potencjał regeneracyjny w badanych warunkach kultury charakteryzował rośliny 
z rodziny Liliaceae i Araceae, mniejszy rośliny należące do Amaryllidaceae, a najmniejszy rośliny z rodziny Iridaceae. Rośliny $\mathrm{z}$ rodziny Liliaceae wyróżnialy się również największą zdolnością tworzenia kalusa, natomiast rośliny z Amaryllidaceae i Iridaceae względnie słabą. Badano wpływ regulatorów wzrostu z grupy auksyn (NAA, IAA, 2,4-D) i cytokinin (K) na przebieg i inicjację organogenezy. Wyniki badań wskazują, że auksyny we współdziałaniu z kinetyną dawały najwyższy procent regenerujących eksplantatów, a także dużą liczbę pąków na eksplantacie. Najsilniejszą stymulację tkanki kalusowej stwierdzono pod wpływem 2,4-D, natomiast słabszą z NAA i IAA: 